\title{
BATISTA, Fernando Teixeira. Fernando Namora - retratos ficcionais de um país real. Pref. de José Manuel Mendes. Ribeirão: Húmus, 2016. 428 p.
}

Claudio Maringelli

Universidade do Algarve, Algarve / Portugal

claudio.maringelli@outlook.com

Recebido em 24 de abril de 2017

Aprovado 5 de maio de 2017

Fernando Namora - Retratos Ficcionais de um País Real resulta da tese de doutoramento de Fernando Teixeira Batista, defendida em 2014 na Universidade do Porto, e apresenta uma análise da trajetória literária de Fernando Namora desde as primeiras obras publicadas até à maturidade, com uma particular atenção à participação do escritorao neorrealismo.

O livro, dividido em quatro partes, segue uma ordem cronológica, escolhendo algumasobras como objeto de estudomais aprofundado. Por isso, estabelece ligações com o conjunto da produção literária do escritor e abre espaços para desenvolver temas de ordem teórica relativos a determinados momentos desse percurso literário de Fernando Namora.

A Parte I consta de quatro capítulos: os primeiros três analisam a fase inicial de Fernando Namora, em particular o romance Fogo na noite escura (1943), que contém uma versão ficcionada do nascimento do movimento neorrealista numa Coimbra dominada pela Universidade. O quarto capítulo é dedicado à apresentação dum largo e atento quadro teórico do movimento neorrealista em geral, aos conteúdos artísticos e 
narratológicos na produção teórica neorrealista e ao debate entre os jovens neorrealistas e os presencistas. Particularmente interessante é a atenção dada à influência sobre o neorrealismo de referências estrangeiras, nomeadamente a literatura de cariz realista dos Estados Unidos (Erskine Caldwell, John dos Passos e, sobretudo, John Steinbeck) e da literatura nordestina brasileira (Jorge Amado, Graciliano Ramos e Lins do Rego).

A Parte II faz a análise das obras da chamada fase rural do autor (1945-1954), com um foco especial sobre Retalhos da vida de um médico

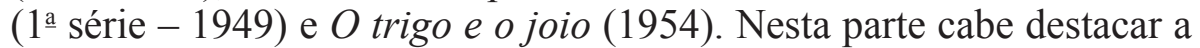
relevância dada por Fernando Teixeira Batista a dois domínios essenciais para o conhecimento da obra de Namora: o espaço autobiográfico (presente ao longo de toda a obra do escritor) e a relação com literatura picaresca, patente sobretudo em $O$ trigo e o joio.

A Parte III e IV tratam as obras da maturidade de Fernando Namora. A Parte III analisa, em particular, O homem disfarçado (1957) e Retalhos da vida de um médico (2 ${ }^{\text {a }}$ série - 1963), procurando encontrar os traços de continuidade e de diversidade entre os títulos anteriores e as obras desta fase urbana, com influências existencialistas. É importante destacar que Batista propõe uma visão fluida do neorrealismo, o que, de acordo com o próprio Namora, significa que aquele movimento nunca recusou nem mudanças, nem o interesse por aspetos psicológicos ou existenciais da vida humana.

A Parte IV, finalmente, estuda as obras de Namora de género misto (cadernos do escritor, narrativas de viagens, narrativas ensaísticas, crónicas), até culminar em O Rio Triste (1982), considerado por Batista como o livro-soma da produção literária namoriana. De novo sobressaem os aspetos de continuidade entre $O$ Rio Triste e o resto da obra de Namora (o espaço autobiográfico, os aspetos sociais e económicos da vida, a visão da cidade como espaço de inautenticidade, por exemplo) e, por outro lado, os elementos de novidade (os traços do género policial e as caraterísticas labirínticas da composição narrativa ligadas à influência do pós-modernismo).

Fernando Namora - Retratos Ficcionais de um País Real oferece um panorama exaustivo da produção do escritor de Condeixaa-Nova, em que a análise literária prevalece sobre a biografia, e em que as leituras teóricas e críticas contemporâneas às publicações de Namora são acompanhadas por contributos e abordagens mais recentes. Neste sentido, o livro destina-se a um público de estudiosos e especialistasde 
estudos literários que queiram aprofundar a visão de conjunto da obra de Namora ou dar-lhe um uso mais pontual, no caso de investigações sobre determinadas obras. Esta última utilização é de resto facilitada pela presença de um índice remissivo exaustivo e pela opção de Batista de recuperar várias vezes alguns conceitos fundamentais ao longo do livro. Cabe frisar, contudo, que esta tendência facilitadora da compreensão isolada de cada (breve) capítulo torna, às vezes, a leitura um tanto repetitiva, o que dificulta o acompanhamento da evolução da análise crítica desenvolvida ao longo de todo o ensaio.

O livro não apresenta um número elevado de citações das obras de Fernando Namora. Esta escolha justifica-se, provavelmente, pela exigência de limitar a extensão total do volume, tendo como objetivo dar um panorama geral da produção do escritor. Daí resultam, em alguns casos, afirmações que parecem parcialmente subjetivas e ganhariam mais sustentação se fossem acompanhadas pelas palavras do próprio Namora. Em contrapartida, poderia ter menos espaço a citação das acusações feitas à suposta pobreza estilística do neorrealismo, embora Fernando Batista, na esteira do próprio Namora, demostre a falta de fundamento deste lugar comum de muita crítica literária portuguesa.

Não restem, em todo o caso, quaisquer dúvidas de que este ensaio de Fernando Teixeira Batista representa um instrumento precioso para aprofundar a leitura da obra de Fernando Namora. Antes de tudo, pela quantidade e qualidade das informações e propostas de leitura apresentadas e, depois, porque é o estudo crítico mais abrangente e exaustivo publicado em Portugal sobre a obra de Namora, retomando o legado crítico dos anos 1960-70 de Mário Sacramento, Taborda de Vasconcelos ou Pierrette e Gérard Chalendar. Neste sentido, a recente reedição pela Editorial Caminho de Retalhos da vida de um médico e $O$ Rio Triste e a recente publicação de outros contributos críticos, sobretudo os de Yana Andreeva e Antony Cardoso Bezerra (que já enriquecem o trabalho de Fernando Teixeira Batista), parecem ser sinais da necessária redescoberta deste escritor, cujo centenário do nascimento se comemorará em 2019. A este quadro junta-se com toda a evidência o livro Fernando Namora - Retratos Ficcionais de um País Real, instrumento fundamental para a investigação literária sobre Namora e sobre a prosa portuguesa da segunda metade do século XX. 